\title{
PENGARUH BERMAIN LARI ESTAFET TERHADAP PERKEMBANGAN MOTORIK KASAR ANAK KELOMPOK B USIA 5-6 TAHUN TK YASPA PALEMBANG
}

\author{
Bibit Retno Sari ${ }^{1}$, Santa Idayana Sinaga, M.Pd ${ }^{2}$ \\ Email: retnosaribibit@gmail.com², santashmily@gmail.com²
}

\begin{abstract}
Abstrak: Dimasa usia dini anak perlu mendapatkan stimulasi yang baik karena dimasa ini, anak mengalami kemajuan yang sangat pesat dalam semua bidang aspek perkembangan, salah satunya motorik kasar. Penelitian ini bertujuan untuk mengetahui pengaruh bermain lari estafet terhadap perkembangan motorik kasar anak kelompok B usia 5-6 Tahun TK Yaspa Palembang. Jenis penelitian kuantitatif dengan metode penelitian eksperimen menggunakan true eksperimental design dengan bentuk prettest-posttest control group design. Teknik pengumpulan data observasi dan dokumentasi. Sampel penelitian berjumlah 30 orang anak terdiri dari B1 dan B2. Berdasarkan perhitungan yang diperoleh untuk prettest kelas eksperimen 0,06 dan posttest kelas eksperimen 0,08 kedua data tersebut berdistribusi normal. Hasil perhitungan uji homogenitas data untuk $F_{\text {hitung }}$ $\leq \mathrm{F}_{\text {tabel }}$ atau 1,28 $\leq 2,48$ varians dalam penelitian ini homogen. Hasil perhitungan hipotesis uji $\mathrm{t}$, diperoleh $t_{\text {hitung }} 4,53 \geq \mathrm{t}_{\text {tabel }} 2,048$, berarti tolak Ho dan terima Ha maka terdapat pengaruh bermain lari estafet terhadap perkembangan motorik kasar anak kelompok B usia 5-6 tahun TK Yaspa Palembang.
\end{abstract}

Kata Kunci: Lari Estafet, Motorik Kasar, Anak Usia Dini

PENDAHULUAN

Pendidikan Anak Usia Dini diselenggarakan dengan tujuan untuk memfasilitasi pertumbuhan dan perkembangan anak secara menyeluruh. Pendidikan Anak Usia Dini perlu memfasilitasi anak untuk belajar tentang aspek-aspek perkembangan seperti nilai-nilai agama dan moral, kognitif, bahasa, motorik dan sosial-emosional. Pendidikan anak usia dini merupakan salah satu bentuk penyelenggaraan pendidikan yang menitik-beratkan pada peletakan dasar kearah pertumbuhan dan perkembangan. Sesuai dengan keunikan dan tahaptahap perkemangan yang dilalui oleh anak usia dini.

$$
\text { Usia dini merupakan masa }
$$
penting untuk mengoptimalkan pertumbuhan dan perkembangan anak. Dimasa usia dini anak perlu mendapatkan stimulasi yang baik karena dimasa ini, anak mengalami kemajuan yang sangat pesat dalam semua bidang aspek perkembangan. Dari beberapa aspek perkembangan tersebut, yang perlu dikembangkan 
adalah motorik kasar. Saat anak melakukan kegiatan dengan temantemannya anak membutuhkan kemampuan gerak dasar yang baik agar dapat mengimbangi gerak teman sebayanya seperti berjalan, berlari, melakukan gerak kelincahan, keseimbangan, koordinasi dan lain sebagainya. Perkembangan motorik kasar dipengaruhi oleh kematangan dan stimulasi. Perkembangan motorik kasar ditandai dengan perubahan gerak sederhana ke yang kompleks. Pada masa golden age, anak perlu mendapatkan stimulasi yang baik untuk meningkatkan aspek perkembangan anak, terutama aspek perkembangan motorik kasar. Perkembangan motorik kasar anak dapat distimulasi melalui kegiatan bermain. Bermain adalah aktivitas kegiatan yang dilakukan seseorang individu yang sifatnya menyenagkan. Melalui bermain anak dapat belajar banyak hal, dapat berinteraksi dengan anak lain, mengekspresikan diri, dan mengembangkan kemampuannya serta membuat anak aktif bergerak.

Fenomena di atas diperkuat oleh penelitian Soraya (2017), dengan judul "Upaya Meningkatkan Keterampilan Motorik Kasar Anak Kelompok B Melalui Bermain Estafet Di TK PKK Marsudi siwi Pleret Bantul". Jurnal Pendidikan Anak Usia Dini Universitas Negeri Yogyakarta. Data yang diperoleh bahwa melalui bermain estafet terdapat peningkatan keterampilan motorik kasar anak. Adapun hasil yang diperoleh dari penelitian keterampilan motorik kasar anak saat pratindakan sebesar $30,70 \%$ berada pada kriteria sedang, pada siklus I meningkat menjadi $70,37 \%$ pada kriteria tinggi. Namun peningkatan tersebut belum mampu memenuhi kriteria keberhasilan, maka dilakukan perbaikan pada siklus II meningkat menjadi $85,24 \%$ pada kriteria sangat tinggi.

Penelitian selanjutnya diperkuat oleh Ningrum dan Khasanah (2017), dengan judul "Meningkatkan Kedisiplinan Anak Usia 3-4 Tahun Melalui Metode Bermain Bola Estafet Di PPT Hasanah Terpadu Sambikerep Surabaya". Data yang diperoleh bahwa pelaksanaan kegiatan bermain Bola Estafet dapat meningkatkan 
kedisiplinan anak. Adapun hasil yang diperoleh dari penelitian, kedisiplinan anak pada siklus I tingkat perkembangannya memperoleh persentase sebesar $59,25 \%$ dengan kriteria belum sesuai harapan, karena belum mampu memenuhi kriteria keberhasilan, maka dilakukan perbaikan pada siklus II meningkat dengan persentase $85,64 \%$ dengan kriteria sesuai harapan.

Kondisi yang tidak jauh berbeda terjadi pada anak kelompok B TK Yaspa Palembang. Hal ini terlihat ketika anak diberi tantangan untuk bermain melewati garis rintanagan oleh ibu guru TK Yaspa Palembang, masih banyak anak yang berlari lambat, anak terlihat lesu serta malas untuk bergerak. Penyebab masalah tersebut, dikarenakan kegiatan bermain yang dilakukan kurang mendapat perhatian, baik dalam hal penggunaan media dan kegiatan yang dilakukan kurang menarik minat anak. Untuk itu, guru perlu menciptakan kegiatan yang menarik, menyenangkan, dan kegiatan yang dapat disukai anak. maka peneliti tertarik untuk melakukan penelitian dengan judul "Pengaruh Bermain Lari Estafet Terhadap Perkembangan Motorik Kasar Anak Kelompok B Usia 5-6 Tahun TK Yaspa Palembang.

\section{TINJAUAN PUSTAKA}

\section{Bermain Lari Estafet}

Menurut Elfiadi (2016 : 53), dijelaskan bahwa bermain adalah keseluruhan aktivitas yang dilakukan oleh seseorang individu yang sifatnya menyenangkan, mengembirakan, dan menimbulkan kenikmatan yang berfungsi untuk membantu individu mencapai perkembangan yang utuh, baik fisik, intelektual, sosial, moral, dan emosional. Bermain merupakan kegiatan yang menyenangkan tanpa beban dan tanpa paksaan untuk dilakukan anak. Kurniati (2016 : 04), menjelaskan bahwa bermain adalah cara bagi anak untuk memperoleh pengetahuan tentang segala sesuatu. Bermain akan menumbuhkan anak untuk melakukan eksplorasi, melatih pertumbuhan fisik serta imajinasi, mengembangkan bahasa, dan membuat belajar jadi menyenangkan. 
Jadi bermain merupakan kegiatan yang dapat memberikan informasi atau pengetahuan, memberikan kesenagan serta dapat mengembangkan imajinasi serta aspek perkembangan anak. Selanjutnya Risaldy (2015 : 42), menjelaskan bahwa bermain merupakan hak yang bersifat mendasar bagi anak usia dini. Memiliki nilai utama dan hakiki pada masa pra-sekolah. Di dalam bermain anak memiliki nilai kesempatan untuk mengekspresikan sesuatu yang ia rasakan dan pikirkan. Bermain dapat memberikan kesempatan yang seluas-luasnya untuk meningkatkan aspek perkembangan yang ada dalam diri anak.

Dari pengertian para ahli di atas, dapat disimpulkan bahwa bermain adalah aktivitas kegiatan yang dilakukan seseorang individu, yang sifatnya menyenangkan, dapat memberikan informasi atau menambah wawasan pengetahuan anak, sehingga melalui bermain dapat meningkatkan aspek perkembangan anak.
Adapun Susanto (2016 : 22), menjelaskan lari estafet adalah lari yang dilakukan secara bersambung atau bergantian oleh suatu tim. Setiap pelari harus menempati titik start masing-masing. Pelari pertama akan lari terlebih dahulu menuju pelari kedua sambil membawa tongkat. Setelah sampai di tempat pelari kedua, tongkat berpindah tangan dan pelari kedua harus meneruskan tongkat itu pada pelari berikutnya. Lari estafet merupakan lari bergantian dengan membawa tongkat yang dilakukan secara berkelompok, setiap pelari memiliki start yang berbeda-beda.

Menurut Eci (2017 : 33), lari estafet adalah lomba lari sambungmenyambung untuk mengantarkan tongkat menuju garis akhir. Dalam satu tim bekerja sama untuk bergantian membawa tongkat estafet menuju garis finish. Lari estafet merupakan kegiatan lari sambung yang dilakukan secara berkelompok untuk mengantarkan tongkan sampai ke garis finish.

Dari penjelasan menurut para ahli di atas dapat disimpulkan bahwa lari estafet adalah lari sambung untuk 
mengantarkan atau memindahkan tongkat kegaris finish, yang dilakukan secara berkelompok, dan setiap pelari memiliki start yang berbeda-beda. Jadi bermain lari estafet adalah suatu kegiatan yang menyenangkan yang dapat meningkatkan aspek perkembangan anak, bermain lari estafet dilakukan dengan cara lomba lari dengan memindahkan tongkat dari satu pelari kepelari berikutnya sampai garis finish, yang dilakukan dalam bentuk kelompok.

Berikut ini teknik atau cara bermain lari estafet menurut Wiarto (2013 : 18-21), yaitu (a) Pelari pertama menggunakan start jongkok.

(b) Pelari kedua dan seterusnya menggunakan star melayang (berdiri). (c) Ketika ada aba-aba "Bersedia, Siap, Ya", permainan dimulai. pelari pertama menuju pelari kedua dengan membawa tongkat, pelari kedua menuju pelari ketiga dan seterusnya.

\section{Perkembangan Motorik Kasar}

Menurut Desmita (2015 : 4-5), menjelaskan perkembangan adalah perubahan yang berlangsung secara terus menerus, menghasilkan bentukbentuk dan ciri-ciri kemampuan baru yang berlangsung dari tahap aktivitas yang sederhana ketahap yang lebih tinggi, perkembangan bergerak secara berangsur-angsur melalui suatu tahap-ketahap berikutnya yang kian hari kian bertambah maju. Perkembangan merupakan perubahan-perubahan yang dialami individu menuju tingkat kedewasaan atau kematangan.

Selanjutnya Suryana (2018 : 177 - 178), menjelaskan motorik kasar adalah gerak tubuh yang menggunakan otot-otot besar atau sebagian besar atau seluruh anggota tubuh yang dipengaruhi oleh kematangan anak. Contohnya kemampuan duduk, menendang berlari, dan naik turun tangga.

Rohendi, dkk (2017 : 20 - 21), menjelaskan bahwa perkembangan motorik adalah suatu proses yang sejalan dengan penambahan usia di mana secara bertahap dan berkesinambungan gerakan individu meningkat dari sederhana ke yang kompleks, dari yang tidak terorganisir menjadi terorganisir 
dengan baik, dan pada akhirnya ke arah penyesuaian keterampilan terjadi proses menua, sebagai akibat interaksi antara faktor biologis (kematangan) dan pengalaman siklus kehidupan manusia. Menurut Sumiyati (2018 : 86 - 87), perkembangan motorik kasar anak adalah hal penting yang perlu diperhatikan dan perlu mendapatkan stimulasi, berikut ini aspek-aspek perkembangan motorik kasar anak yaitu aspek kekuatan, daya tahan, kecepatan, keseimbangan, koordinasi, kelincahan, dan ketepatan.

\section{Berdasarkan}

pengertian

beberapa pendapat para ahli di atas, dapat disimpulkan bahwa perkembangan motorik kasar merupakan perubahan gerak otot-otot besar dari gerak sederhana ke yang kompleks dipengaruhi oleh kematangan serta stimulasi, dan beberapa aspek yang terdapat dalam perkembangan motorik kasar anak yaitu aspek kekuatan, daya tahan, kecepatan, keseimbangan, koordinasi, kelincahan, dan ketepatan.
Adapun faktor-faktor yang mempengaruhi perkembangan motorik individu, menurut Rahyubi (2016 : 226 - 227) adalah a) Sistem Saraf, sistem saraf sangat berpengaruh dalam perkembangan motorik karena sistem saraflah yang mengontrol aktivitas motorik pada tubuh manusia. b) Kondisi Fisik, perkembangan motorik sangat erat kaitannya dengan fisik, maka kondisi fisik tentu saja sangat berpengaruh pada perkembangan motorik seseorang. Seseorang yang memiliki fisik normal biasannya perkembangan motoriknya akan lebih baik dibandingkan orang lain yang memiliki kekurangan fisik. c) Motivasi yang Kuat, seseorang yang punya motivasi yang kuat untuk menguasai keterampilan motorik tentu biasanya telah punya modal besar untuk meraih prestasi. Kemudian, ketika seseorang mampu melakukan suatu aktivitas motorik dengan baik, maka kemungkinan besar dia akan termotivasi untuk menguasai keterampilan motorik yang lebih luas dan lebih tinggi lagi. d) Lingkungan yang Kondusif, perkembangan motorik seseorang 
individu kemungkinan besar bisa berjalan optimal jika lingkungan tempatnya beraktivitas mendukung dan kondusif. Lingkungan disini bisa berarti fasilitas, peralatan, sarana, dan prasarana. e) Aspek Psikologis, seseorang yang kondisi psikologisnya baik maka akan mampu meraih keterampilan motorik yang baik pula. Meskipun punya fisik yang mendukung, namun jika kondisi psikologis seseorang tidak berada dalam kondisi yang baik atau tidak mendukung, maka sulitlah baginya untuk meraih keterampilan motorik yang optimal dan memuaskan. f) Usia, usia sangat berpengaruh pada aktivitas motorik seseorang. Karena dengan bertambahnya usia, berarti akan menunjang tercapainya kematangan, sehingga akan memudahkan seseorang untuk melakukan berbagai gerak. g) Jenis Kelamin, dalam kemampuan motorik, tertentu, misalnya olahraga, faktor jenis kelamin cukup berpengaruh. Dalam beberapa cabang olahraga seperti sepak bola, lari, dan lain sebagainya, laki-laki tentu lebih kuat, lebih cepat, lebih trampil, dan lebih gesit dibandingkan perempuan. Anak lakilaki lebih dominan menyukai aktivitas motorik kasar, sedangkan anak perempuan lebih dominan motorik halus. h) Bakat dan Potensi, berpengaruh pada usaha meraih keterampilan motorik. Misalnya, seseorang mudah diarahkan untuk menjadi pesepak bola andal jika dia punya bakat dan potensi sebagai pemain bola. Begitu juga pada bidang keterampilan motorik lainnya. Meskipun begitu, bakat bakat dan potensi bukan satu-satunya faktor yang bisa menjamin kesuksesan seseorang untuk meraih keterampilan motorik tertentu. Masih banyak variabel lain yang mempengaruhi keterampilan motorik, diantaranya harus ada kemauan, keuletan, dan usaha yang kuat untuk meraih keterampilan motorik yang diangankan.

\section{METODOLOGI PENELITIAN}

Dalam penelitian ini terdapat dua variabel, yaitu variabel independen (bebas) dan variabel dependen (terikat). Variabel bebas pada penelitian ini adalah bermain lari estafet yang dilambangkan dengan (X). Dan variabel terikat 
pada penelitian ini adalah perkembangan motorik kasar yang dilambangkan dengan (Y). Penelitian ini dilaksanakan di kelompok B1 TK Yaspa Palembang. Beralamatkan Di Jl. A. Yani. Lr. Amilin. No. 985. Rt. 16 Palembang. Provinsi Sumatra Selatan. Penelitian ini dilaksanakan pada semester genap tahun 2019 yaitu pada bulan Juni 2019. Penentuan waktu penelitian mengacu pada kelender akademik sekolah. Penelitian ini berlangsung selama 8 kali pertemuan, guna memperoleh data yang akurat. Metode yang digunakan dalam penelitian ini adalah metode Eksperimen dengan menggunakan true eksperimental design dengan bentuk desain prettest-posttest control group design.

Populasi adalah wilayah generalisasi yang terdiri atas obyek/subyek yang mempunyai kualitas dan karakteristik tertentu yang ditetapkan oleh peneliti untuk dipelajari dan kemudian ditarik kesimpulannya (Sugiyono, 2017 : 117). Populasi dalam penelitian ini adalah kelompok B, yang terdiri dari kelompok B1 15 anak, kelompok B2
15 anak dan kelompok B3 10 anak di TK Yaspa Palembang yang keseluruhannya berjumlah 40 orang. Menurut Riduwan (2013 : 56), sampel adalah bagian dari populasi yang mempunyai ciri-ciri atau keadaan tertentu yang akan diteliti. Adapun sampel dalam penelitian ini menggunakan teknik random sampling. Random sampling yaitu penentuan sampel secara acak dengan mengundi. Untuk menentukan kelas eksperimen dan kelas kontrol dilakukan dengan undian daftar seluruh kelas yang akan dijadikan sampel. Kelas yang terpilih pada undian pertama dijadikan kelas eksperimen, sedangkan pada undian kedua dijadikan kelas kontrol. Demikian anggota kelas eksperimen yang diambil secara acak (random) yang muncul pada undian pertama yaitu anak kelas B1 dengan jumlah 15 orang anak, yang terbagi anak lakilaki berjumlah 6 orang anak dan anak perempuan dengan jumlah 9 orang anak, sedangkan kelas kontrol yang diambil secara acak (random) yang muncul pada undian kedua yaitu anak kelas B2 dengan jumlah 15 
orang anak, yang terbagi anak lakilaki berjumlah 8 orang, dan anak perempuan dengan jumlah 7 orang, jadi sampel dalam penelitian ini yaitu kelas eksperimen B1 dan kelompok kelas kontrol B2 TK Yaspa Palembang.

Rancangan perlakuan dalam penelitian ini adalah tahap pemberian tes awal (Pretest) baik kelompok eksperimen maupun kelompok kontrol diberi Pretest berupa bermain melewati garis rintanagan. Tahap pemberian perlakuan yaitu peneliti memberikan perlakuan (Treatment) yang berbeda terhadap kelompok eksperimen dan kelompok kontrol. Pada kelompok eksperimen diberi perlakuan dengan bermain lari estafet dan pada kelompok kontrol tidak diberi perlakuan dengan bermain lari estafet tetapi dengan memberikan kegiatan bermain dengan bola. Tahap tes akhir (Posttest) dilakukan dan dinilai sama pada saat dilakukannya Pretest.

Teknik pengumpulan data penelitian ini yaitu dengan observasi dan dokumentasi. Hasil uji coba penelitian ini menggunakan uji validitas (Judgement Experts) yang dilakukan pertama kali yaitu validitas instrumen, kemudian ahli menilai aspek-aspek tentang perkembangan motorik kasar yang akan diujikan kepada anak. Adapun indikator perkembangan motorik kasar anak adalah (a) Anak mampu berlari dengan penuh semangat. (b) Anak mampu melangkahkan kaki secara bergantian dengan cepat saat melakukan kegiatan berpindah tempat. (c) Anak mampu menjaga keseimbangan tubuhnya saat berpindah tempat tanpa terjatuh. (d) Anak mampu menjaga keseimbagan tubuhnya saat berdiri pada satu tempat. (e) Anak mampu melakukan koordinasi gerak dengan tepat. (f) Anak mampu melakukan koordinasi gerak dengan terarah.

\section{HASIL DAN PEMBAHASAN}

\section{Hasil}

\section{a. Uji Normalitas Data}

Hasil data posttest kelas eksperimen adalah 60,00 sedangkan prettest kelas eksperimen 42,03 Berdasarkan dari hasil perhitungan posttest kelas eksperimen di dapat nilai $\mathrm{km}=0,08$ sedangkan prettest kelas eksperimen di dapat nilai $\mathrm{km}=$ 
0,06 maka dari kedua data tersebut berdistribusi normal.

\section{b. Uji Homogenitas Data}

Uji homogenitas yang peneliti gunakan yaitu menggunakan uji varians. Ternyata $F_{\text {hitung }}$ lebih kecil dari $\mathrm{F}_{\text {tabel }}(1,28<2,48)$. Dengan demikian dapat disimpulkan bahwa varians dalam penelitian ini homogen.

\section{c. Uji Hipotesis}

Hipotesis dalam penelitian ini adalah $\mathrm{H}_{\mathrm{a}}$ diterima jika $t_{\text {hitung }}>\mathrm{t}_{\text {tabel }}$ dan $H_{o}$ ditolak jika $t_{\text {hitung }}<t_{\text {tabel. }}$. Berdasarkan hitungan tersebut diperoleh $t_{\text {hitung }} 4,53$ dan berdasarkan $\mathrm{dk}$ dengan taraf 5\% maka diperoleh $t_{\text {tabel }}$ 2,048 sesuai dengan kriteria pengujian hipotesis, yakni jika thitung $>$ $t_{\text {tabel }} \mathrm{H}_{\mathrm{a}}$ diterima dan $\mathrm{H}_{\mathrm{o}}$ ditolak. Dengan demikian hasil penelitian ini menunjukkan ada pengaruh yang signifikat bermain lari estafet terhadap perkembangan motorik kasar anak kelompok B TK Yaspa Palembang.

\section{Pembahasan}

Motorik kasar anak perlu mendapatkan stimulasi agar dapat berkembang dengan optimal, sehingga diperlukan suatu kegiatan yang menarik salah satunya yaitu dengan bermain. Bermain merupakan kebutuhan bagi anak karena melalui bermain anak akan memperoleh pengetahuan yang dapat mengembangkan kemampuan yang ada dalam dirinya. Ketika bermain anak mendapatkan kesempatan untuk melakukan kegiatan yang banyak melibatkan gerak tubuh, sehingga membuat tubuh anak menjadi sehat.

Sejalan dengan hal tersebut, hasil penelitian ini di dukung oleh penelitian Wardani, dkk (2018) dengan judul "Permainan Modifikasi Lari Estafet Terhadap Perkembangan Motorik Kasar Anak Usia 4-5 Tahun TK Aisyiyah Bustanul Atfal Yosomulyo". Data yang diperoleh bahwa permainan lari estafet berpengaruh terhadap perkembangan motorik kasar anak. Ada perbedaan yang signifikan antara kelas yang mendapat perlakuan kegiatan modifikasi lari estafet dengan kelas yang tidak mendapat perlakuan kegiatan modifikasi lari estafet. Kondisi awal perkembangan motorik kasar anak sebelum perlakuan terdapat satu anak mulai berkembang 
dan dua puluh sembilan anak belum berkembang, setelah diberikan perlakuan, perkembangan motorik kasar anak meningkat yaitu dua anak mulai berkembang dan dua puluh delapan anak berkembang sesuai harapan. Adapun hasil yang diperoleh dari penelitian, bahwa terdapat pengaruh yang positif permainan modifikasi lari estafet terhadap perkembangan motorik kasar anak usia 4-5 tahun.

Selanjutnya, Sujiono (2013 : berpendapat bahwa, pembelajaran anak usia dini menganut pendekatan bermain sambil belajar atau belajar sambil bermain, dengan bermain anak-anak menggunakan otot tubuhnya, menstimulasi indera-indera tubuhnya, mengeksplorasi dunia sekitarnya, fIsik anak akan terlatih kemampuan kognitif dan kemampuan berinteraksi dengan orang lain akan berkembang.

\section{KESIMPULAN DAN SARAN}

Dapat disimpulkan bahwa:

1. Bermain lari estafet adalah suatu kegiatan yang menyenangkan yang dapat meningkatkan aspek perkembangan anak, bermain lari estafet dilakukan dengan cara lomba lari dengan memindahkan tongkat dari satu pelari kepelari berikutnya sampai garis finish, yang dilakukan dalam bentuk kelompok.

2. Dari hasil penelitian yang peneliti lakukan, kegiatan bermain lari estafet dapat memberikan pengaruh terhadap perkembangan motorik anak menjadi lebih baik. Kegiatan yang dilakukan pun menarik dan menyenangkan, adapun hasil perhitungan yang di dapat yaitu sebagai berikut (a) Data prettest kelas eksperimen uji normalitas data adalah 0,06 dan posttest kelas eksperimen diperoleh 0,08 harga tersebut terletak antara (-1) dan (1) sehingga dapat dikatakan bahwa kedua data tersebut berdistribusi normal. (b) Kemudian hasil perhitungan uji homogenitas data untuk $F_{\text {hitung }} \leq \mathrm{F}_{\text {tabel }}$ atau $1,28 \leq 2,48$ dengan demikian varians dalam penelitian ini homogen. Setelah pengujin normalitas data dan homogenitas data tersebut terdistribusi normal dan homogen, maka tahap berikutnya dilakukan pengujian hipotesis. (c) Dari hasil perhitungan uji $t$, diperoleh nilai 
$\mathrm{t}_{\text {hitung }}=4,53$ jika dibandingkan dengan $\mathrm{t}_{\text {tabel }} 28=2,048$, maka $\mathrm{t}_{\text {hitung }}$ $4,53 \geq \mathrm{t}_{\text {tabel }} 2,048$, berarti tolak Ho dan terima Ha. Maka dari itu hipotesis penelitian ini, terdapat pengaruh bermain lari estafet terhadap perkembangan motorik kasar anak kelompok B usia 5-6 tahun TK Yaspa Palembang.

Adapun saran yang perlu diperhatikan yaitu:

1. Perlu adanya bimbingan dan latihan untuk mengembangan aspek perkembangan yang ada dalam diri anak, salah satunya aspek perkembangan motorik kasar.

2. Kegiatan tersebut dapat berupa bermain lari estafet, melalui kegiatan bermain lari estafet akan memberikan kesenangan dan kegembiraan pada diri anak. Selain itu, aspek perkembangan anak dapat terstimulasi dengan baik terutama aspek perkembangan motorik kasar.

\section{DAFTAR PUSTAKA}

Desmita. Pisikologi Perkembangan. Bandung: PT Remaja Rosdakarya.

Elfiadi, (2016). Bermain dan Permainan Bagi Anak Usia Dini. Diakses dari http://ejournal.iainIhokse umawe.ac.id/index.php/it qan/article/view/15. Pada tanggal 09 januari 2019 pada pukul 18:27.

Fe, Eci. (2017). Buku Pintar Olahraga \& Permainan Tradisional. Jogjakarta: Laksana.

Khasanah, Nur, dan Mallevi Agustin Ningrum, (2017). Meningkatkan

Kedisiplinan Anak Usia 3-4 Tahun Melalui Metode Bermain Bola Estafet Di PPT Hasanah Terpadu Sambikerep Surabaya. Diakses dari https://jurnalmahasiswa.u nesa.ac.id, pada tanggal 07 Januari 2019 pada pukul 20:44.

Kurniati, Euis. (2016). Permainan Tradisional. Jakarta: Prenadamedia Group.

Rahyubi, Heri. (2016). Teori-Teori Belajar Dan Aplikasi Pembelajaran Motorik. Bandung: Nusa Media.

Riduwan. (2013). Belajar Mudah Penelitian. Bandung: Alfabeta.

Risaldy, Sabil. (2015). Bermain, Bercerita \& Menyanyi Bagi Anak Usia Dini. Jakarta: PT. Luxima Metro Media

Rohendi, Asep, dkk. (2017). Perkembangan Motorik. Bandung: Alfabeta. 
Soraya, Risky Aulia. (2017). Upaya Meningkatkan

Keterampilan Motorik Kasar Anak Kelompok B Melalui Bermain Estafet Di TK PKK Marsudisiwi Pleret Bantul. Diakses dari

https://eprints.uny.ac.id> Pada tanggal 15 Januari 2019 pada pukul 19:01.

Sugiyono. (2017). Metode Penelitian Pendidikan. Bandung: Alfabeta, cv.

Sujiono, Yuliani Nurani. (2013). Konsep Dasar Pendidikan Anak Usia Dini. Jakarta: PT Indeks.

Sumiyati. (2017). Metode Pengembangan Motorik Kasar Anak Usia Dini. Diakses dari www.syekhnurjati.ac.id./j urnal/index.php/awlady.

Pada tanggal 17 Desember 2018 pada pukul 15:32.

Suryana, Dadan (2018), Stimulasi \& Aspek Perkembangan Anak. Jakarta: Prenadamedia Group.

Susanto, Teguh. (2016). Buku Pintar Olahraga. Yogyakarta: Pustaka Baru Press.

Pada tanggal 15 Januari 2019 pada pukul 22:27.

Wardani, Nurul Irma dkk. 2018. Permainan Modifikasi Lari Estafet Terhadap Perkembangan Motorik Kasar Anak Usia 5-4 Tahun di TK Aisyiyah
Bustanul Atfal Yosomulyo. Diakses dari Jurnal Pendidikan Anak, 2018jurnal.fkip.unila.ac.id pada tanggal 12 Maret 2018 pada pukul 18:40.

Wiarto, Giri, (2013). Atlentik. Yogyakarta: Graha Ilmu. 